\title{
Fjöldi tannlækna á Íslandi \\ - spá um fjölda tannlækna fram til ársins 2040
}
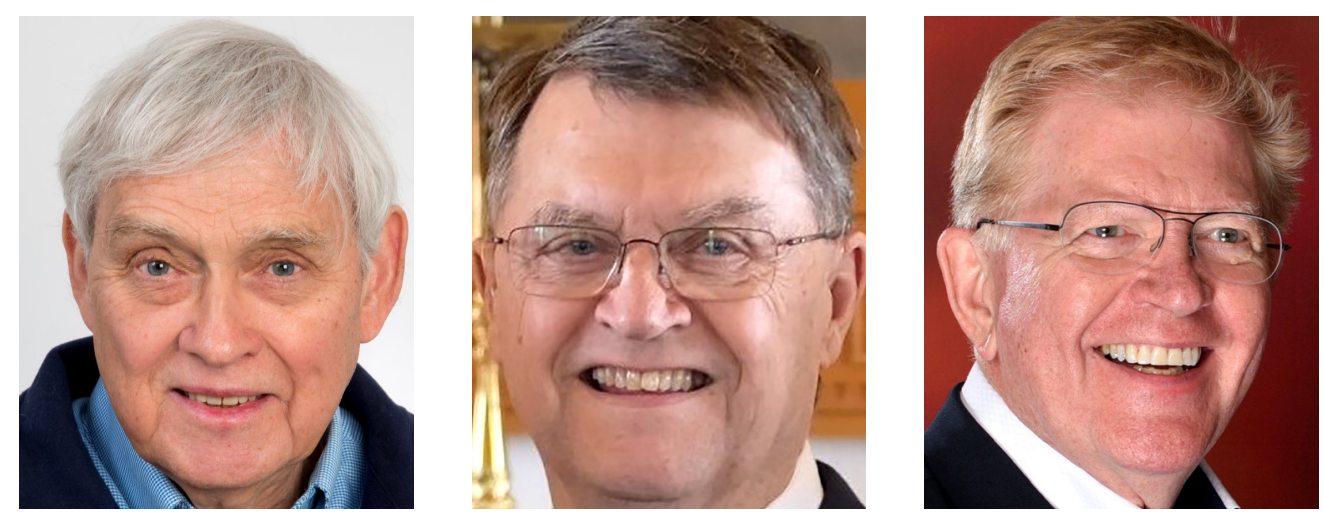

BÖRKUR THORODDSEN, CAND. ODONT. DMD

SVEND RICHTER, CAND. ODONT. MS. DÓSENT EMERITUS, TANNLAEKNADEILD HÁSKÓLA ÍSLANDS

SIGFÚS PÓR ELÍASSON, CAND. ODONT. MSD, PRÓFESSOR EMERITUS, TANNLAEKNADEILD HÁSKÓLA ÍSLANDS, VÍSINDAMAĐUR, NIOM, OSLO, NOREGI

NETFANG: BTHOR@XNET.IS, SVEND@HI.IS, SIGFUSE@HI.IS

TANNLAKKNADEILD, HÁSKÓLA ÍSLANDS, TANNLAKKNABLAĐIĐ 2019; 37: 16-26

doi: 10.33112/tann.37.1.2

\section{ÁGRIP}

Íbúafjöldi hér á landi 1. apríl 2019 var 358.780. Tannlæknar voru á sama tíma 284 sem gerir 1.263 íbúa á tannlækni. Á sama tíma bjuggu 45.670 erlendir ríkisborgarar á Íslandi eða 12.7\% af heildarmannfjölda. Íslenskir ríkisborgargar eru 313.110 eða 1.103 íbúar á tannlækni. Í nýlegri mannfjöldaspá er gert ráð fyrir að íslendingum fjölgi nokkuð á næstu árum. Einnig mun öldruðum fjölga hlutfallslega meira en ungu fólki vegna aukins langlífis og lækkandi fæðingartíðni. Ef miðað væri við að tannlæknar hættu störfum 67 ára, væru á pessu ári um 1.416 íbúar á hvern tannlækni á Íslandi en 1.237 ef erlendir ríkisborgarar hér væru ekki taldir með. Ef miðað er við að 8 tannlæknar útskrifist árlega frá Tannlæknadeild Hí og einn tannlæknir komi erlendis frá má gera ráð fyrir, miðað við sömu forsendur og miðspá mannfjöldaspár Hagstofu Íslands gangi eftir, að 1.356 íbúar verði á tannlækni árið 2030 og að hlutfallið haldist nánast óbreytt til 2040. Ef einungis íbúar með íslenskt ríkisfang eru taldir, yrði hlutfallið 1.185 árið 2030 og svipað 2040. Ef miðað er við að tannlæknar hætti sjötugir yrðu samsvarandi tölur árið 2030 1.259 og 1.100. Í báðum tilfellum er hlutfallið hærra en í Danmörku, Noregi og Svíðjóð.Tannlækningar eldri borgara, sérstaklega tenntra, lasburða gamalmenna á vistheimilum verður krefjandi og tímafrekt viðfangsefni í framtíðinni. Telja verður að atvinnuhorfur tannlækna séu góðar auk pess sem nægilegur fjöldi tannlækna ætti að vera tiltækur á næstu áratugum. Rannsóknir á tannheilsu pjóðarinnar skortir til opinberar stefnumótunar í málaflokknum.

Lykilorð: Fjöldi tannlækna, mannfjöldaspá, Ísland 


\section{Inngangur}

pað er allra hagur að fjöldi íbúa á hvern tannlækni sé hæfilegur. Óskynsamlegt er að mennta of fáa eða of marga tannlækna. Rekstrarkostnaður tannlæknaskóla er mikill (1). Ungt fólk sem hefur tannlæknanám væntir pess að fá starf og hæfileg verkefni i starfsgrein sinni að loknu námi. Námið er langt og strangt og svo sérhæft að menntunin nýtist trauðla á öðrum vettvangi. Skortur á tannlæknum leiðir til pess að ekki er hægt að veita alla pá pjónustu sem pörf er á. Nú útskrifast 8 tannlæknar á ári frá Tannlæknadeild Háskóla Íslands (2).

Fólksfjölgun hefur verið mikil á Íslandi undanfarin ár. Frjósemi er með pví mesta sem pekkist í Evrópu (3), pó að frjósemi kvenna á Íslandi árið 2018 hafi verið minni en nokkru sinni áður eða 1,7 barn á hverja konu (4). Er pað svipað hlutfall og á hinum Norðurlöndum. Aðalástæðan fyrir mikilli fólksfjölgun nú er að fjöldi útlendinga af ýmsum pjóðernum hefur komið tímabundið til Íslands til að vinna. pað sem meðal annars einkennir farandverkamenn á íslandi er peir eru flestir karlar sem dvelja hér í stuttan tíma (5). Hagstofa Íslands skilgreinir innflytjanda sem einstakling sem er fæddur erlendis og á foreldra sem einnig eru fæddir erlendis, svo og báđir afar og ömmur. Önnur kynslóð innflytjenda eru einstaklingar sem fæddir eru á Íslandi og eiga foreldra sem báðir eru innflytjendur. Ekki eru allir útlendingar skráđir innflytjendur hjá Hagstofu Íslands. Farandverkamenn sem koma til fárra mánaða dvalar purfa ekki að vera skráðir, jafnvel pótt peir taki laun, greiði skatta og hafi kennitölu. Sama gildir með útlendinga sem vinna hjá starfsmannaleigum.

pegar spáð er um fjölda tannlækna sem mennta parf næstu ár, er nauðsynlegt að vita hve margir íbúar hafa fasta búsetu og hve margir starfa tímabundið á Íslandi. Gera má ráð fyrir að innflytjendur hafi i mörgum tilfellum tímabundna búsetu á Íslandi. Pessi hópur er síđur líklegur til að sækja mikla tannlæknispjónustu. Farandverkamenn frá löndum par sem verðlag er lágt leita oft einungis eftir bráđapjónustu hér á landi, en sækja frekari meðferð í heimalandinu. Öðru máli gegnir með annarrar kynslóðar innflytjendur. Peir eru 1,3\% mannfjöldans og eru nú flestir á aldrinum 0 - 17 ára og teljast Íslendingar (6). Aðflutningur nefnist pað pegar einstaklingur hefur fasta búsetu í öđru ríki en pví landi sem hann fæddist í. Innflytjendur koma í mörgum tilvikum til með að búa í landinu sem peir flytja til í mörg ár jafnvel út ævina og hljóta pá oft ríkisborgararétt. Ferðamenn og aðrir gestir sem koma tímabundið til landsins teljast ekki innflytjendur, né heldur flóttamenn. Farandverkamenn á hinn bóginn eru oft flokkaðir sem innflytjendur (6). Erfitt er að spá um áhrif innflytjenda á fólksfjöldann til lengri tíma. Yfir 2.3 milljónir ferðamanna komu til landsins 2018 og áđu mislengi (7). Tannlæknapjónusta í formi bráđapjónustu er einhver, en óvíst hversu mikil.

Rannsóknir sýna samband milli tekna og tannheilsu. Meiri eftirspurn er eftir pjónustu tannlækna pegar efnhagur árar vel og ráđstöfunartekjur einstaklinga/heimila er meiri. Alpjóðaheilbrigðisstofnunin, WHO, hefur bent á að sterkt samband milli munnheilsu og menntunar, félags- og efnahagsstöðu einstaklinga sem staðfest er í erlendum og íslenskum rannsóknum (8-10).

Pörf á pjónustu tannlækna má skipta í klínískar parfir og parfir sem almenningur telur sig purfa. Mestu máli skiptir tíðni algengustu tannsjúkdóma og tannheilsuvitund almennings. Aðrir pættir sem hafa áhrif á eftirspurn á tannlæknapjónustu eru meðal annars (11):

- Aukin ævilengd.

- Aukið hlutfall háskólamenntaðra.

- Fjölgun innflytjenda og frá hvaða löndum peir koma.

- Aukin notkun lyfja sem valda munnpurrki.

- Auknar útlitskröfur.

- Ađgengi íbúa að tannlæknum.

- Breytingar á ráđstöfunartekjum fólks.

- Breytingar á kostnaðarhlutdeld sjúkratrygginga i tannlækniskostnaði

Höfundar rituðu grein í Tannlæknablaðið 2008 par sem spáð var í fjölda tannlækna fram til 2030 (12). Ekki er vitað um önnur spálíkön um petta efni hér á landi.

Markmið rannsóknarinnar sem pessi grein byggir á, er að kanna hversu margir tannlæknar eru nú við störf hér á landi, hlutfall tannlækna á íbúa og að kanna út frá mannfjöldaspám Hagstofu Íslands hvernig petta hlutfall muni breytast í framtíðinni, miðað við á hvaða aldri tannlæknar hætta störfum og hvernig nýliðun tannlækna verður. Niðurstöður eru bornar saman við staðtölur frá hinum Norðurlöndum.

\section{Efni og aðferðir}

Upplýsingar um aldur, búsetu og fjölda starfandi tannlækna voru fengnar hjá Tannlæknafélagi Íslands. Upplýsingar um íbúafjölda, aldursamsetningu, hlutfall innflytjenda og mannfjöldaspá voru fengnar og unnar úr gögnum frá Hagstofu Íslands. İ öllum útreikningum um tannlæknafjölda var notast við miðspá Hagstofunnar. Upplýsingar um fjölda stúdenta í tannlæknanámi voru fengnar hjá Tannlæknadeild Háskóla Íslands og Lánasjóði íslenskra námsmanna. Einnig var leitað fanga í staðtölum frá nágrannalöndum og erlendum fagtímaritum, sem fjallað hafa um efnið. 
Í spánni um fjölda íbúa á tannlækni er gert ráð fyrir að peir tannlæknanemar, sem eru nú við nám útskrifist á réttum tíma.

Tölfræðiúrvinnsla var unnin í Microsoft Exel (Microsoft Corporation, Remond, WA. USA).

Kannað var annars vegar hlutfall íbúa á tannlækni pegar innflytjendur eru ekki taldir með og hins vegar pegar peir eru taldir með, til að sjá hvernig pessar breytur hafa áhrif á hlutfallið. Ekki er í útreikningum gert ráð fyrir að Íslendingar sæki tannlæknispjónustu erlendis.

\section{Niðurstöður}

1. apríl 2019 var íbúafjöldi hér á landi 358.780 og hafði landsmönnum fjölgað um 1.730 á fyrsta ársfjórðungi ársins. 1. janúar 2019 var íbúafjöldinn 357.050 og hafði fjölgað frá sama tíma 2018 um 8600 eđa nálægt 2.5\% (13).

Árið 2018 voru Pólverjar fjölmennasti hópur innflytjenda, 16.970 einstaklingar eða 38,8\% allra innflytjenda 16.970 eða 38,8\% allra innflytjenda. Par á eftir koma innflytjendur frá Litháen, 5,5\% og frá Filippseyjum, 4,0\%. Einstaklingar af annarri kynslóð innflytjenda voru 4.861 manns. Samanlagt er fyrsta og önnur kynslóð innflytjenda 13,9\% af mannfjöldanum $(6,14)$.

Hagstofa Íslands hefur framreiknað mannfjöldann fyrir tímabilið 2018-2067 á grundvelli tölfræðilíkana fyrir búferlaflutninga, frjósemi og dánartíðni. Dánartíđni er lág og fæðingartíðni há í evrópsku samhengi $(3,15)$. Spáin gerir ráð fyrir meiri fólksfjölgun en fyrri spár sögðu til um. Verulegar breytingar á aldurssamsetningu pjóðarinnar eru fyrirsjáanlegar á næstu áratugum. Öldruðum mun fjölga hlutfallslega meir en börnum. Gerð eru prjú afbrigði af framreikningnum; miðspá, háspá og lágspá. Spáafbrigðin byggja á mismunandi forsendum um hagvöxt til næstu fimm ára, frjósemishlutfall og búferlaflutninga. Einnig er gerð grein fyrir próun mannfjöldans og samsetningu á tímabilinu (15).

Fjöldi aðfluttra verður hærri en fjöldi brottfluttra ár hvert samkvæmt öllum spáafbrigðum, fyrst og fremst vegna erlendra innflytjenda. Íslenskir ríkisborgarar sem flytja frá landinu verða áfram fleiri en peir sem flytja til landsins (15).

Breytingar á aldurssamsetningu manna sjást mjög vel pegar litið er á aldurspíramíða miðspárinnar í upphafi og lok spátímabilsins (Mynd 1). ÆEtla má að íbúar landsins verði 436 púsund árið 2067 samkvæmt miðspá Hagstofunnar um próun mannfjöldans. Til samanburðar var mannfjöldinn 348 púsund 1. janúar 2018. Í háspánni er reiknað með að íbúar verði 513 púsund í lok spátímabilsins en 365 púsund samkvæmt lágspánni, og munar par 148 púsund manns (15).

Samkvæmt miðspánni verða dánir fleiri en fæddir á hverju ári frá og með árinu 2061, en frá og með árinu 2041 samkvæmt lágspánni. Hinsvegar fæðast fleiri en deyja á hverju ári spátímabilsins samkvæmt háspánni. Meðalævi karla og kvenna við fæðingu mun halda áfram að lengjast. Nýfæddar stúlkur árið 2018 gátu vænst pess að verða 83,9 ára gamlar en nýfæddir drengir 79,8 ára. Stúlkur sem fæðast árið 2067 geta vænst pess að verða 88,7 ára en drengir 84,4 ára. Gangi miðspáin eftir verður fjölgun í nær öllum aldurshópum, en pó einkum í peim elstu. Árið 2035, verður hlutfall peirra sem eru eldri en 65 ára yfir 20\% mannfjöldans og árið 2057 yfir 25\%. Hlutfallið er nú 14\%. Hlutfall peirra sem eru eldri en 85 ára byrjar hins vegar ekki að aukast fyrr en árið 2028, en fram að pví verður pað innan
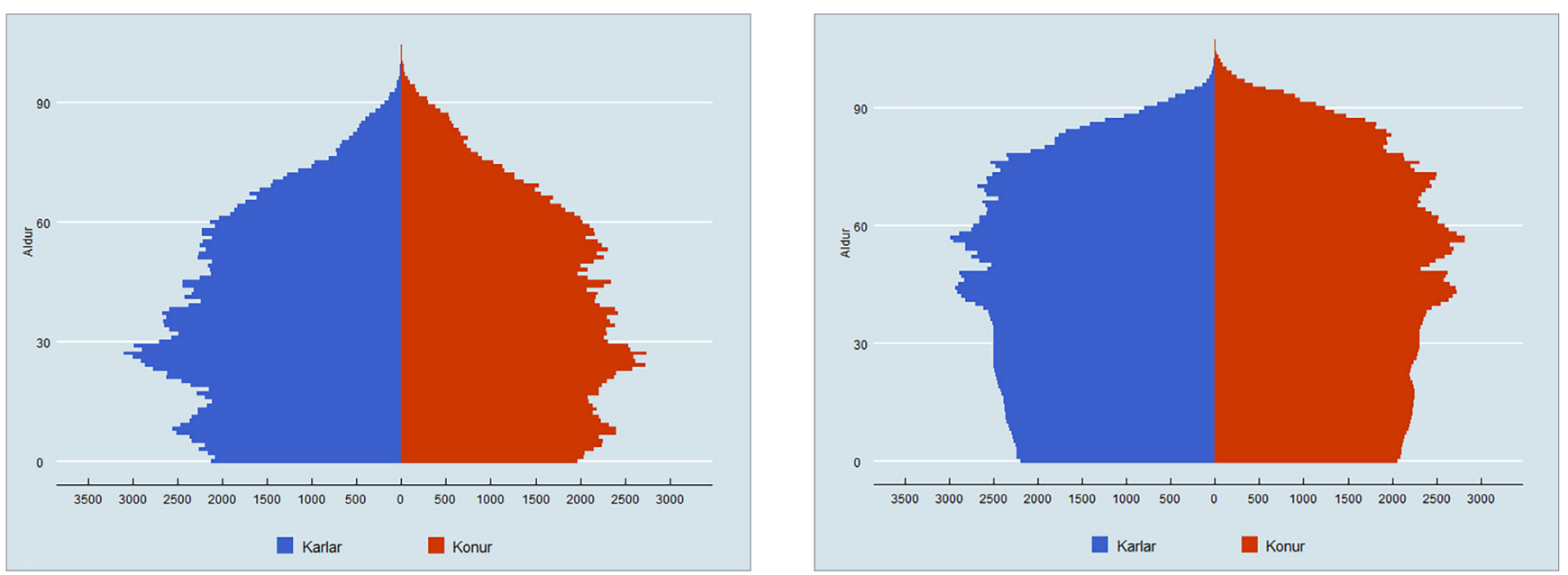

Mynd 1. Aldurspíramídarnir 2018 og 2067, miðspá. Heimild: Hagstofa Íslands(15).

Figure 1. Population age pyramids 2018 and 20167, medium variant. Source: Statistics Iceland(15). 


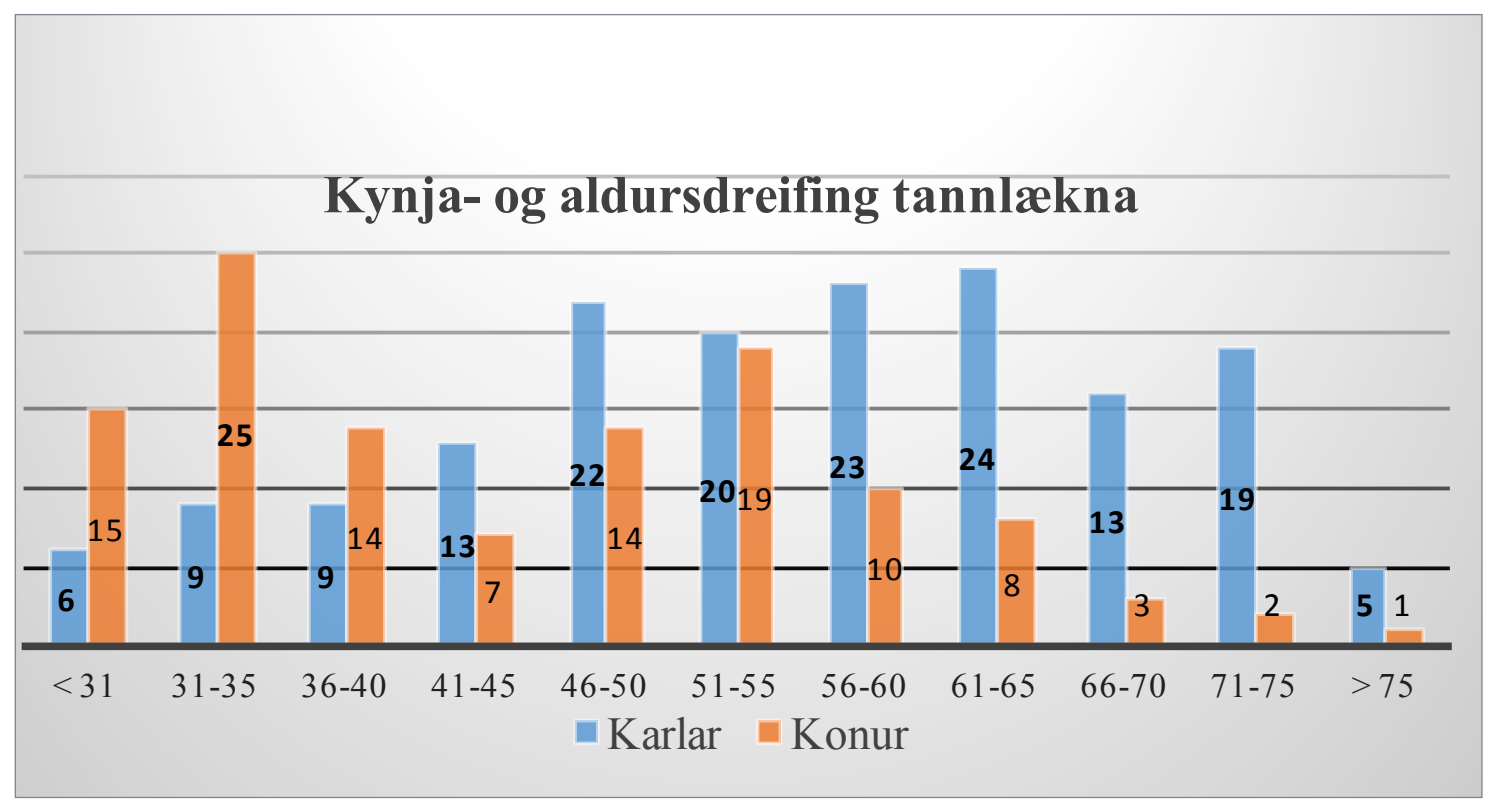

Mynd 2. Aldurs- og kynjadreifing íslenskra tannlækna árið 2018.

Figure 2. Age and gender distribution of Icelandic dentists 2018.

Fjöldi íbúa á tannlækni. Íslenskt ríkisfang - 9 tannlæknar útskrifast á ári frá THí

\begin{tabular}{|c|c|c|c|c|c|c|c|c|c|}
\hline Ár & Íbúar - 12,6\% & Fjöldi tannl. & Hlutfall & Fjöldi tannl. & Hlutfall & Fjöldi tannl. & Hlutfall & Fjöldi tannl. & Hlutfall \\
\hline \multicolumn{2}{|c|}{ Starfslok tannlækna: } & \multicolumn{2}{|c|}{ Hætta 65 ára } & \multicolumn{2}{|c|}{ Hætta 67 ára } & \multicolumn{2}{|c|}{ Hætta 70 ára } & \multicolumn{2}{|c|}{ Hætta 74 ára } \\
\hline 2019 & 311.825 & 240 & 1.299 & 252 & 1.237 & 266 & 1.172 & 282 & 1.106 \\
\hline 2020 & 318.054 & 243 & 1.309 & 259 & 1.228 & 270 & 1.178 & 286 & 1.112 \\
\hline 2021 & 323.744 & 244 & 1.327 & 261 & 1.240 & 274 & 1.182 & 289 & 1.120 \\
\hline 2022 & 329.182 & 246 & 1.338 & 264 & 1.247 & 280 & 1.176 & 293 & 1.123 \\
\hline 2023 & 334.603 & 251 & 1.333 & 265 & 1.263 & 287 & 1.166 & 298 & 1.123 \\
\hline 2024 & 334.544 & 256 & 1.307 & 267 & 1.253 & 289 & 1.158 & 302 & 1.108 \\
\hline 2025 & 334.282 & 257 & 1.301 & 272 & 1.229 & 292 & 1.145 & 306 & 1.092 \\
\hline 2026 & 333.820 & 256 & 1.304 & 277 & 1.205 & 293 & 1.139 & 312 & 1.070 \\
\hline 2027 & 333.165 & 260 & 1.281 & 278 & 1.198 & 295 & 1.129 & 319 & 1.044 \\
\hline 2028 & 332.308 & 263 & 1.264 & 277 & 1.200 & 300 & 1.108 & 321 & 1.035 \\
\hline 2029 & 334.489 & 268 & 1.248 & 281 & 1.190 & 305 & 1.097 & 324 & 1.032 \\
\hline 2030 & 336.610 & 265 & 1.270 & 284 & 1.185 & 306 & 1.100 & 325 & 1.036 \\
\hline 2031 & 338.679 & 267 & 1.268 & 289 & 1.172 & 305 & 1.110 & 327 & 1.036 \\
\hline 2032 & 340.688 & 270 & 1.262 & 286 & 1.191 & 309 & 1.103 & 332 & 1.026 \\
\hline 2033 & 342.636 & 269 & 1.274 & 288 & 1.190 & 312 & 1.098 & 337 & 1.017 \\
\hline 2034 & 344.533 & 269 & 1.281 & 291 & 1.184 & 317 & 1.087 & 338 & 1.019 \\
\hline 2035 & 346.379 & 274 & 1.264 & 290 & 1.194 & 314 & 1.103 & 337 & 1.028 \\
\hline 2036 & 348.190 & 272 & 1.280 & 290 & 1.201 & 316 & 1.102 & 341 & 1.021 \\
\hline 2037 & 349.957 & 275 & 1.273 & 295 & 1.186 & 319 & 1.097 & 344 & 1.017 \\
\hline 2038 & 351.669 & 278 & 1.265 & 293 & 1.200 & 318 & 1.106 & 349 & 1.008 \\
\hline 2039 & 353.335 & 283 & 1.249 & 296 & 1.194 & 318 & 1.111 & 346 & 1.021 \\
\hline 2040 & 354.948 & 284 & 1.250 & 299 & 1.187 & 323 & 1.099 & 348 & 1.020 \\
\hline
\end{tabular}

Tafla 1. Fjöldi ibúa með islenskt rikisfang á tannlækni ef 9 tannlæknar bætast við árlega og tannlæknar hætta störfum 65, 67, 70 eða 74 ára.

Table 1. Number of Icelandic citizens per dentist if 8 dentists graduate each year in Iceland, one comes from abroad and dentists retire at 65, 67, 70 or 74 years of age. 
Fjöldi íbúa á tannlækni. Allir íbúar. - 9 tannlæknar útskrifast á ári

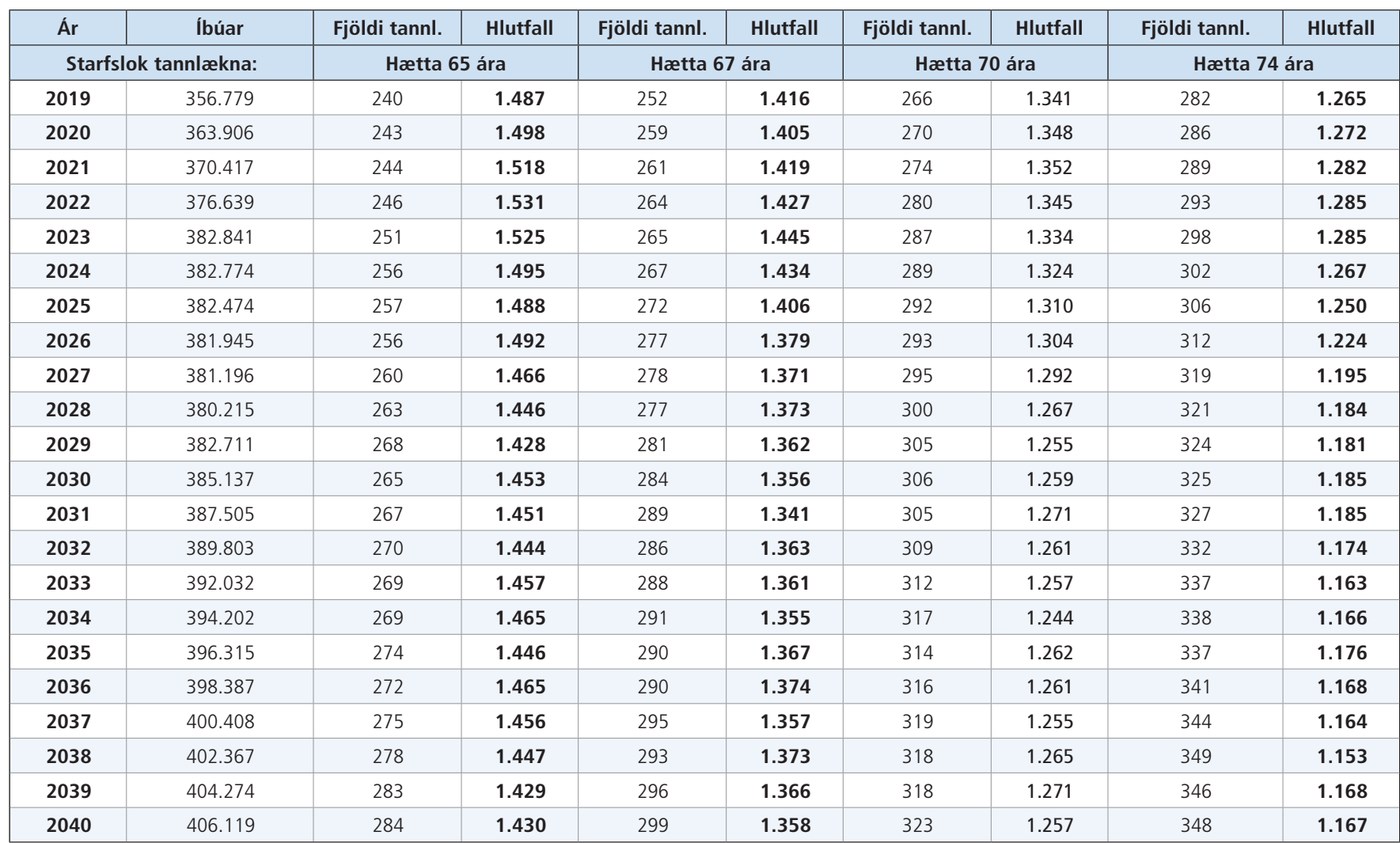

Tafla 2. Heildarfjöldi íbúa, islensk rikisfang og innflytjendur, á tannlækni ef 9 tannlæknar bætast við árlega og tannlæknar hætta störfum 65, 67, 70 eða 74 ára. Table 2. Total number of inhabitants, Icelandic citizens and immigrants, per dentist if 8 dentists graduate each year in Iceland, one comes from abroad and dentists retire at $65,67,70$ or 74 years of age.

Fjöldi íbúa á tannlækni. Íslenskt ríkisfang. Tannlæknar hætta 67 ára

\begin{tabular}{|c|c|c|c|c|c|c|c|c|c|c|c|c|c|}
\hline Ár & Íbúar-12,6\% & Fj. $\operatorname{tannl}$. & Hlutfall & Fj. $\operatorname{tannl}$. & Hlutfall & Fj. tannl. & Hlutfall & Fj. tannl. & Hlutfall & Fj. tannl. & Hlutfall & Fj. tannl. & Hlutfall \\
\hline \multicolumn{2}{|c|}{ Fj útskrifast } & \multicolumn{2}{|c|}{5 á ári } & \multicolumn{2}{|c|}{6 á ári } & \multicolumn{2}{|c|}{7 á ári } & \multicolumn{2}{|c|}{8 á ári } & \multicolumn{2}{|c|}{9 á ári } & \multicolumn{2}{|c|}{10 á ári } \\
\hline 2019 & 311.825 & 248 & 1.257 & 249 & 1.252 & 250 & 1.247 & 251 & 1.242 & 252 & 1.237 & 253 & 1.233 \\
\hline 2020 & 318.054 & 251 & 1.267 & 253 & 1.257 & 255 & 1.247 & 257 & 1.238 & 259 & 1.228 & 261 & 1.219 \\
\hline 2021 & 323.744 & 249 & 1.300 & 252 & 1.285 & 255 & 1.270 & 258 & 1.255 & 261 & 1.240 & 264 & 1.226 \\
\hline 2022 & 329.182 & 248 & 1.327 & 252 & 1.306 & 256 & 1.286 & 260 & 1.266 & 264 & 1.247 & 268 & 1.228 \\
\hline 2023 & 334.603 & 245 & 1.366 & 250 & 1.338 & 255 & 1.312 & 260 & 1.287 & 265 & 1.263 & 270 & 1.239 \\
\hline 2024 & 334.544 & 243 & 1.377 & 249 & 1.344 & 255 & 1.312 & 261 & 1.282 & 267 & 1.253 & 273 & 1.225 \\
\hline 2025 & 334.282 & 244 & 1.370 & 251 & 1.332 & 258 & 1.296 & 265 & 1.261 & 272 & 1.229 & 279 & 1.198 \\
\hline 2026 & 333.820 & 245 & 1.363 & 253 & 1.319 & 261 & 1.279 & 269 & 1.241 & 277 & 1.205 & 285 & 1.171 \\
\hline 2027 & 333.165 & 242 & 1.377 & 251 & 1.327 & 260 & 1.281 & 269 & 1.239 & 278 & 1.198 & 287 & 1.161 \\
\hline 2028 & 332.308 & 237 & 1.402 & 247 & 1.345 & 257 & 1.293 & 267 & 1.245 & 277 & 1.200 & 287 & 1.158 \\
\hline 2029 & 334.489 & 237 & 1.411 & 248 & 1.349 & 259 & 1.291 & 270 & 1.239 & 281 & 1.190 & 292 & 1.146 \\
\hline 2030 & 336.610 & 236 & 1.426 & 248 & 1.357 & 260 & 1.295 & 272 & 1.238 & 284 & 1.185 & 296 & 1.137 \\
\hline 2031 & 338.679 & 237 & 1.429 & 250 & 1.355 & 263 & 1.288 & 276 & 1.227 & 289 & 1.172 & 302 & 1.121 \\
\hline 2032 & 340.688 & 230 & 1.481 & 244 & 1.396 & 258 & 1.320 & 272 & 1.253 & 286 & 1.191 & 300 & 1.136 \\
\hline 2033 & 342.636 & 228 & 1.503 & 243 & 1.410 & 258 & 1.328 & 273 & 1.255 & 288 & 1.190 & 303 & 1.131 \\
\hline 2034 & 344.533 & 227 & 1.518 & 243 & 1.418 & 259 & 1.330 & 275 & 1.253 & 291 & 1.184 & 307 & 1.122 \\
\hline 2035 & 346.379 & 222 & 1.560 & 239 & 1.449 & 256 & 1.353 & 273 & 1.269 & 290 & 1.194 & 307 & 1.128 \\
\hline 2036 & 348.190 & 218 & 1.597 & 236 & 1.475 & 254 & 1.371 & 272 & 1.280 & 290 & 1.201 & 308 & 1.130 \\
\hline 2037 & 349.957 & 219 & 1.598 & 238 & 1.470 & 257 & 1.362 & 276 & 1.268 & 295 & 1.186 & 314 & 1.115 \\
\hline 2038 & 351.669 & 213 & 1.651 & 233 & 1.509 & 253 & 1.390 & 273 & 1.288 & 293 & 1.200 & 313 & 1.124 \\
\hline 2039 & 353.335 & 212 & 1.667 & 233 & 1.516 & 254 & 1.391 & 275 & 1.285 & 296 & 1.194 & 317 & 1.115 \\
\hline 2040 & 354.948 & 211 & 1.682 & 233 & 1.523 & 255 & 1.392 & 277 & 1.281 & 299 & 1.187 & 321 & 1.106 \\
\hline
\end{tabular}

Tafla 3. Fjöldi ibúa með islenskt rikisfang á tannlækni ef 5, 6, 7, 8, 9 eða 10 tannlæknar útskrifast árlega og tannlæknar hætta störfum 67 ára.

Table 3. Number of Icelandic citizens per dentist if 5, 6, 7, 8, 9 or 10 dentists graduate each year and dentists retire at 65, 67, 70 or 74 years of age. 
Fjöldi íbúa á tannlækni. Allir Íbúar. Tannlæknar hætta 67 ára

\begin{tabular}{|c|c|c|c|c|c|c|c|c|c|c|c|c|c|}
\hline Ár & Íbúar-12,6\% & Fj. tannl. & Hlutfall & Fj. tannl. & Hlutfall & Fj. tannl. & Hlutfall & Fj. tannl. & Hlutfall & Fj. tannl. & Hlutfall & Fj. tannl. & Hlutfall \\
\hline \multicolumn{2}{|c|}{ Fj útskrifast } & \multicolumn{2}{|c|}{5 á ári } & \multicolumn{2}{|c|}{6 á ári } & \multicolumn{2}{|c|}{7 á ári } & \multicolumn{2}{|c|}{8 á ári } & \multicolumn{2}{|c|}{9 á ári } & \multicolumn{2}{|c|}{10 á ári } \\
\hline 2019 & 356.779 & 248 & 1.439 & 249 & 1.433 & 250 & 1.427 & 251 & 1.421 & 252 & 1.416 & 253 & 1.410 \\
\hline 2021 & 370.417 & 249 & 1.488 & 252 & 1.470 & 255 & 1.453 & 258 & 1.436 & 261 & 1.419 & 264 & 1.403 \\
\hline 2022 & 376.639 & 248 & 1.519 & 252 & 1.495 & 256 & 1.471 & 260 & 1.449 & 264 & 1.427 & 268 & 1.405 \\
\hline 2023 & 382.841 & 245 & 1.563 & 250 & 1.531 & 255 & 1.501 & 260 & 1.472 & 265 & 1.445 & 270 & 1.418 \\
\hline 2025 & 382.474 & 244 & 1.568 & 251 & 1.524 & 258 & 1.482 & 265 & 1.443 & 272 & 1.406 & 279 & 1.371 \\
\hline 2026 & 381.945 & 245 & 1.559 & 253 & 1.510 & 261 & 1.463 & 269 & 1.420 & 277 & 1.379 & 285 & 1.340 \\
\hline 2027 & 381.196 & 242 & 1.575 & 251 & 1.519 & 260 & 1.466 & 269 & 1.417 & 278 & 1.371 & 287 & 1.328 \\
\hline 2028 & 380.215 & 237 & 1.604 & 247 & 1.539 & 257 & 1.479 & 267 & 1.424 & 277 & 1.373 & 287 & 1.325 \\
\hline 2029 & 382.711 & 237 & 1.615 & 248 & 1.543 & 259 & 1.478 & 270 & 1.417 & 281 & 1.362 & 292 & 1.311 \\
\hline 2033 & 392.032 & 228 & 1.719 & 243 & 1.613 & 258 & 1.520 & 273 & 1.436 & 288 & 1.361 & 303 & 1.294 \\
\hline 2034 & 394.202 & 227 & 1.737 & 243 & 1.622 & 259 & 1.522 & 275 & 1.433 & 291 & 1.355 & 307 & 1.284 \\
\hline 2035 & 396.315 & 222 & 1.785 & 239 & 1.658 & 256 & 1.548 & 273 & 1.452 & 290 & 1.367 & 307 & 1.291 \\
\hline 2036 & 398.387 & 218 & 1.827 & 236 & 1.688 & 254 & 1.568 & 272 & 1.465 & 290 & 1.374 & 308 & 1.293 \\
\hline 2037 & 400.408 & 219 & 1.828 & 238 & 1.682 & 257 & 1.558 & 276 & 1.451 & 295 & 1.357 & 314 & 1.275 \\
\hline 2038 & 402.367 & 213 & 1.889 & 233 & 1.727 & 253 & 1.590 & 273 & 1.474 & 293 & 1.373 & 313 & 1.286 \\
\hline 2039 & 404.274 & 212 & 1.907 & 233 & 1.735 & 254 & 1.592 & 275 & 1.470 & 296 & 1.366 & 317 & 1.275 \\
\hline 2040 & 406.119 & 211 & 1.925 & 233 & 1.743 & 255 & 1.593 & 277 & 1.466 & 299 & 1.358 & 321 & 1.265 \\
\hline
\end{tabular}

Tafla 4. Heildarfjöldi ibúa, islenskir rikisborgarar og innflytjendur, á tannlækni ef 5, 6, 7, 8, 9 eða 10 tannlæknar útskrifast árlega og tannlæknar hætta störfum 67 ára. Table 4. Total number of inhabitants, Icelandic citizens and immigrants, per dentist if 5, 6, 7, 8, 9 or 10 dentists graduate each year and dentists retire at 65, 67, 70 or 74 years of age.

við 2\%. Fram til ársins 2060 mun pað hlutfall tvöfaldast og fara yfir 5\% undir lok spátímabilsins. Frá árinu 2046 verða peir sem eru eldri en 65 ára í fyrsta sinni fjölmennari en peir sem eru yngri en tvítugir (15). Mynd 2 sýnir kyn- og aldursdreifingu íslenskra tannlækna árið 2018.

í Töflum 1 og 2 má sjá fjölda tannlækna miðað við fjölda íbúa á hvern tannlækni fram til ársins 2040 miðað við 8 útskrifaða tannlækna árlega hér á landi og einn komi erlendis frá. Tafla 1 sýnir áætlað hlutfall íbúa með íslenskt ríkisfang á tannlækni árlega miðað við mismunandi aldur tannlæknis við starfslok. Í Töflu 2 má sjá hlutfall allra íbúa, bæði með íslenskt ríkisfang og innflytjendur á tannlækni við mismunandi aldur tannlæknis við starfslok. Ef allir tannlæknar hættu störfum 67 ára væru núna 1.237 íbúar með íslenskt ríkisfang á tannlækni, en 1.416 ef innflytjendur eru taldir með. Pessar tölur yrðu 1.187 og 1.358 árið 2040. Ef tannlæknar myndu hætta nú 70 ára, væru íbúar með íslenkt ríkisfang á tannlækni nú 1.172, en 1.341 ef innflytjendur eru taldir með og árið 2040 yrðu pessar tölur 1.099 og 1.257. Í Töflum 3 og 4 má sjá áætlaðan fjölda íbúa á tannlækni árin 2019 - 2040 miðað við mismunandi fjölda tannlækna sem kæmu á vinnumarkað árlega og starfslok 67 ára. Ef 10 tannlæknar bætast við árlega væru 1.1219 íbúar með íslensk ríkisfang á tannlækni árið 2020 en 1.394 ef innflytjendur eru taldir með. Árið 2040 yrðu pessar tölur 1.106 og 1.265 .

\section{Umræða}

Mannfjöldaspá áranna 2018 - 2067 gerir ráð fyrir meiri fólksfjölgun en fyrri spár gerðu ráð fyrir. Dánartíðni er lág og ungbarnadauði er sá lægsti í heimi. Fæðingartíðni á Íslandi er með pví hæsta sem pekkist í Evrópu, en á síðustu premur árum hefur aðeins dregið úr henni og er hún nú svipuð og hjá hinum Norðurlandapjóðunum sem verma efstu sætin. Verulegar breytingar á aldurssamsetningu pjóđarinnar eru fyrirsjáanlegar á næstu áratugum. Öldruðum mun fjölga hlutfallslega meira en börnum (15).

pótt pjóðin sé að eldast, pá eru Íslendingar nú og verða enn um sinn mun yngri en flestar Evrópupjóðir par sem fæðingartíðni tók áratugum seinna að lækka hér. Árið 2060 verður meira en priðjungur Evrópubúa eldri en 65 ára en einungis um fjórðungur Íslendinga. Gert er ráð fyrir að Íslendingar nái núverandi hlutfalli innan ESB (19\%) árið 2031 (15). 
Mynd 3. Hlutfall 18-79 ára Íslendinga með eigin tennur í munni og hlutfall tannlausra. Heimild: Embætti landlæknis (26).

Figure 3. The proportion of $18-79$ years old with all own teeth $(\geq 28)$ and the proportion of edentulous Icelanders. Source: Directorate of Health (26).

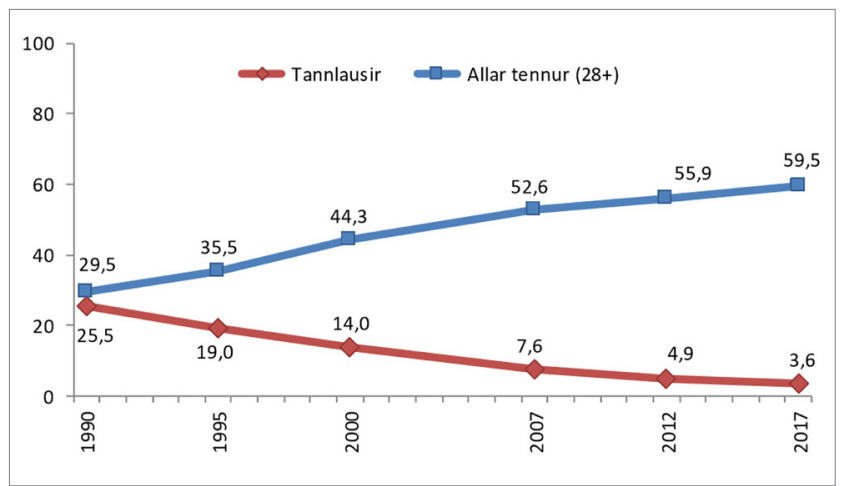

Akureyri. Rannsókninni er meðal annars ætlað að nýtast í opinberri stefnumótun heilbrigðismála, forgangsröðun verkefna og eflingar rannsóknarstarfs. Rannsóknin náđi til íslenskra ríkisborgara, 18-79 ára. Pátttaka var 3.676 manns árið 2007, 6.434 árið 2007 og 6.776 árið 2007. Upplýsingar um munnheilsu er aðeins lítill hluti af pessu verkefni (18). Sjá má niðurstöður pessarar rannsókna á Töflu 5 og Myndum 3-5.

Munnís rannsóknin var gerð að frumkvæði Heilbrigðisog tryggingamálaráđuneytisins og framkvæmd að mestu 2005 og náđi til 20\% allra barna í 1., 7. og 10. bekk víðsvegar um landið. Fram kom að tannáta hafði heldur aukist frá 1995 (19) en endurgreiðsla vegna tannlækninga var lækkuð verulega á tímabilinu. Einnig kom fram að glerungseyðing var orðin algeng (20).Tímabært er að endurtaka MUNNís rannsóknina.

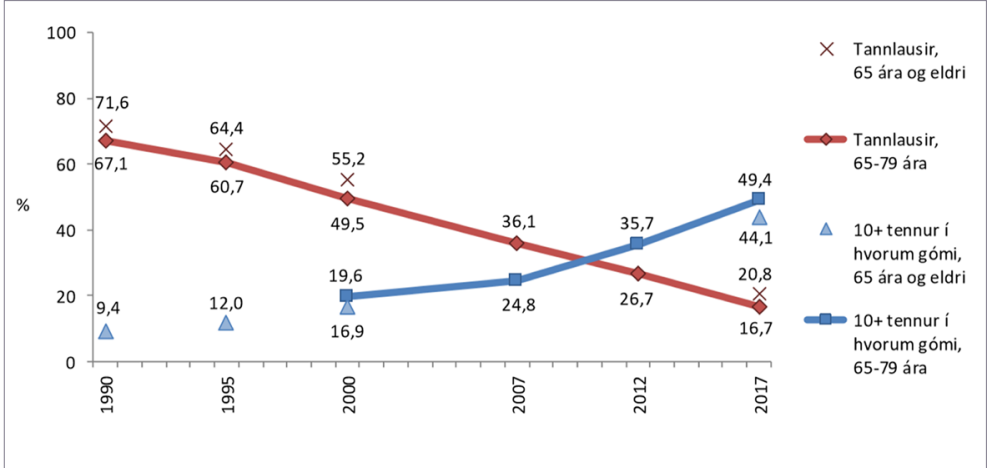

Mynd 4. Hlutfall 65-79 ára og eldri Íslendinga með 10 eða fleiri tennur i hvorum gómi og hlutfall 65-79 ára og 65 ára og eldri tannlausra Íslendinga. Heimild: Embætti landlæknis (26).

Figure 4. The proportion of 65-79 year old Icelanders with 10 or more teeth in each jaw and the proportion of 65-79 and 65 and older edentulous Icelanders. Source: Directorate of Health (26).

Starfsaldur íslenskra tannlækna er hár (Mynd 2) og gera má ráð fyrir að hann sé hærri en annars staðar á Norðurlöndum. pað kann að stafa af pví að stór hluti tannlækna annars staðar starfar sem opinberir starfsmenn, fá góð eftirlaun og hvatinn pví minni að starfa lengur.

Um 12\% danskra tannlækna á eftirlaunaaldri eru enn starfandi. Ein skýring er að tannlæknar í einkapraxís gengur ílla að selja ef tannlæknastofan er utan stærri byggðakjarna. Sé heilsan góð kjósa peir að nota fjáfestingu sína áfram og vinna, etv. í hlutastarfi, ekki ósvipað kollegum hér á landi (16). Víða í Evrópu er gert ráð fyrir að tannlæknar hætti störfum 65 ára, pó að 67 ára eftirlaunaaldur pekkist í nokkrum landanna m.a. í Noregi (17).

Rannsóknarverkefnin Heilsa og líđan Íslendinga 2007, 2012 og 2017 voru gerð hjá Embætti landlæknis í samstarfi við Vinnueftirlit ríkisins, Krabbameinsfélagið, Landspítala, Háskóla Íslands, Háskólann í Reykjavík og Háskólann á
Einn peirra mælikvarða sem gefur vísbendingar um tannheilsu pjóðar byggir á fjölda tanna í munni. Í rannsókninni Heilsa og líđan Íslendinga voru pátttakendur spurðir um fjölda tanna í neðri og efri gómi (18). Í töflu 5 er hægt að bera niðurstöðurnar saman við niðurstöður úr rannsóknum Guðjóns Axelssonar og félaga frá árunum 1990, 1995 og 2000 (18, 21-26).

\begin{tabular}{lcccccc}
\hline & $\mathbf{1 9 9 0}$ & $\mathbf{1 9 9 5}$ & $\mathbf{2 0 0 0}$ & $\mathbf{2 0 0 7}$ & $\mathbf{2 0 1 2}$ & $\mathbf{2 0 1 7}$ \\
\hline 18-44 ára & 51.7 & 57.3 & 65.7 & 77.0 & 79.4 & 84.3 \\
45-54 ára & 14.5 & 21.5 & 36.2 & 40.7 & 47.4 & 55.3 \\
55-64 ára & 3.7 & 6.7 & 13.5 & 20.1 & 27.8 & 36.6 \\
65-79 ára & 2.6 & 2.7 & 3.2 & 7.1 & 9.7 & 16.7 \\
\hline 18-79 ára & 29.5 & 35.5 & 44.3 & 52.6 & 55.9 & 59.5 \\
\hline
\end{tabular}

Tafla 5. Hlutfal 18-79 ára Íslendinga með 28 eða fleiri tennur eftir aldri. Heimild:Embætti landlæknis (26).

Table 5. The proportion of 18-79 year old Icelanders with 28 or more teeth according to age. Source: Directorate of Health (26).

Eins og sjá má í Töflu 3 hefur orðið jákvæð próun á tannheilsu landsmanna. Tæplega 85\% Íslendinga á aldrinum 18- 44 ára voru með allar eigin tennur ( $\geq 28$ tennur) árið 2017, samanborið við rúmlega 50\% árið 1990 (25).

Einnig er ljóst að á sama tíma og fjölgar í hópi fullorðinna sem eru með allar eigin tennur pá fækkar tannlausum jafnt og pétt. Árið 2017 voru 3,6\% Íslendinga á aldrinum 18-79 ára tannlausir samanborið við tæplega 26\% árið 1990 (Mynd 4).

Heilbrigði tanna skiptir miklu máli fyrir almenna heilsu og vellíðan en ákveðinn lágmarksfjöldi eigin tanna í hvorum 


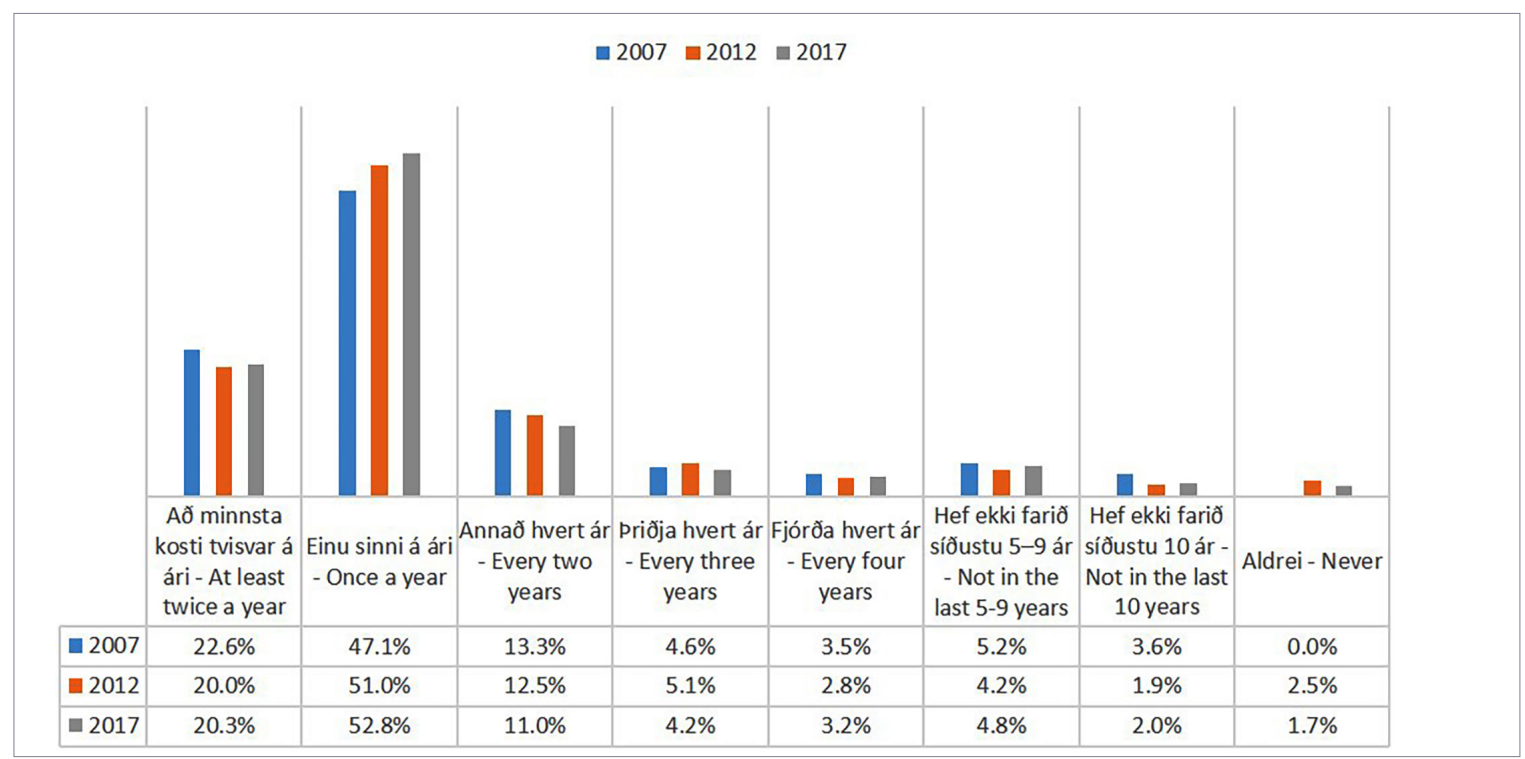

Mynd 5. Eftirlit hjá tannlækni 2007, 2012 og 2017. Heimild: Embætti landlæknis (18).

Figure 5. Visits to dentists 2007, 2012 and 2017. Source: Directorate of Health (18).

gómi, sem miðast gjarnan við 10 tennur, tryggir alla jafna viðunandi tyggingarfærni og tjáningu. Pótt eigin tönnum fækki jafnan með hækkandi aldri pá fjölgar jafnt og pétt í peim hópi 65-79 ára Íslendinga sem eru með 10 eða fleiri tennur í hvorum gómi. Er hlutallið nú tæplega 50\% (Mynd 3) (26).

pað er vissulega jákvætt að fleiri aldraðir eru tenntir, en hefur í för með sér að tannvernd tenntra lasburða gamalmenna á vistheimilum verður krefjandi, tímafrekt og kostnaðarsamt viðfangsefni í framtíðinni. Mikilvægt er pví að beina athygli og fjármunum að tannheilsu aldraðra.

pegar litið er til fjölda starfa meðal tannlækna skiptir máli hversu oft sjúklingar mæta í reglulegt eftirlit. Petta var einnig kannað í rannsókn á vegum embættis Embættis landlæknis. Niðurstöður má sjá í Mynd 5.

Sýnt hefur verið fram á að samband er á milli efnahags og tannheilsu $(9,10)$. I spá Hagstofu Íslands og Seðlabanka Íslands um kaupmátt launa frá og með 2018 til 2023 er gert ráð fyrir nokkurri hækkun kaupmáttar (Mynd 6) (27). Taka verður slíkum spám með fyrirvara, breytingar milli ára geta verið óvissar. Ef litið er til liðinna ára kemur í ljós að efnahagur er misskiptur milli aldurshópa (Mynd 7). Pannig er raunbreyting ráđstöfunartekna á árabilinu 2000 - 2015 mest i elstu aldurshópunum (28). Allt bendir pví til að eldri borgarar munu hækka atvinnustig tannlækna á komandi árum.

Í nýrri skýrslu frá dönsku heilbrigðismálastjórninni má sjá að fjöldi tannlækna í Danmörku var 4.781 árið 2015, sem er 9,8\% færri en árið 2006, en pá var talan 5.257. Fjöldi íbúa á hvern tannlækni var pví 1.184 manns 2015.
Tannlæknum mun fara fækkandi fram til ársins 2030 en mun pá fjölga lítillega til ársins 2040. Konur verða 2/3 hluti tannlækna. Helmingur tannlækna vinnur færri en 32 stundir á viku. Tannfræðingum hefur fjölgað um 31,5\% frá árinu 2006. peir eru nú 2.345 alls og munu verða $42 \%$ fleiri árið 2040. Tannfræðingur, einn eða fleiri er starfandi á $61 \%$ af tannlæknastofum í Danmörku. Helmingur tannfræðinga vinnur i einkapraxis, en 20\% vinna ekki við fagið. 12 klínískir tannsmiðir útskrifast á ári. peir voru 339 árið 2015 og spáð er 37\% aukningu til ársins 2040. Árið 2015 voru 5.660 .000 manns búsettir í Danmörku. Í ofangreindum premur hópum voru alls 6.996 manns starfandi, sem svaraði til að 809 íbúar væru á hvern klínikker (29).

Fram til 1983 útskifuðust 250 tannlæknar árlega í Danmörku en eftir pað einungis 122. Pví fækkar nú tannlæknum hratt eftir pví sem sem pessir stóru árgangar hætta störfum. Verði útskrifuðum tannlæknum ekki fjölgað mun verða verulegur skortur á komandi árum að mati yfirvalda (28). Formaður danska tannlæknafélagsins, Susanne Kleist, lýsir einnig áhyggjum sínum um yfirvofandi tannlæknaskort (16).

Í Noregi hefur verið stöðugur fjöldi tannlækna allt frá snemma á áttunda áratugnum, u.p.b. 1100 íbúar á tannlækni í almennum praxís. Nokkuð hærra hlutfall er í opinberum tannlækningum en í einkapraxís. Fjöldi tannlækna sem koma erlendis frá hefur verið í takt við íbúafjölda. Hins vegar hefur orðið mikil aukning á fjölda sérfræðinga og tannfræðinga. Pannig eru nú yfir 900 tannfræðingar, en voru nánast engir snemma á áttunda áratugnum. Fullyrt er að eftirspurn eftir tannlæknapjónustu 


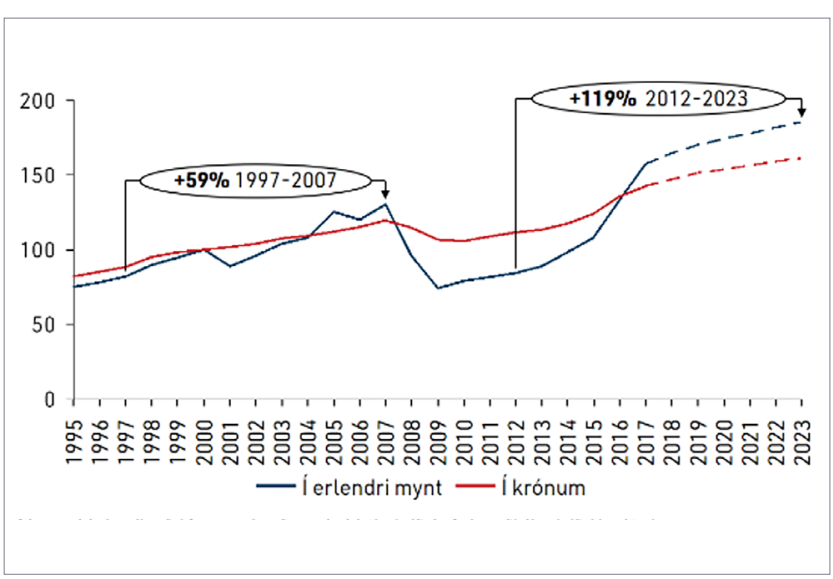

Mynd 6. Kaupmáttur launa. Visitala $2000=100$. Launavísitala er reiknuð á fast gengi með gengisvisitölu. Leiðrétt fyrir verðbólgu í viðskiptalöndum. Heimild: Hagstofa Íslands, Seðlabanki Ísland (27). Figure 6: Wages index for Iceland, year $2000=100$ adjusted with inflation (red line) and exchange rate index (blue line). Source: Statistics Iceland, Central Bank of Iceland (27).

sé hvergi eins mikil nema í löndum sem hafa eins víðtæka pátttöku hins opinbera í kostnaði, til dæmis Svípjóð. Nú fara 80\% fullorðinna Norðmanna reglulega til tannlæknis, að minnsta kosti einu sinni á ári (29). Árið 2017 fóru 73.1\% fullorðinna Íslendinga til tannlæknis að minnsta kosti einu sinni á ári og 11\% annað hvert ár(18). Reikna má með að petta hlutfall hækki verulega með aukinni opinberri pátttöku í kostnaði.

Jostein Grytten prófessor í samfélagstannlækningum í Oslo: „Tilfinningin er sú að tannlæknar í einkapraxís hafi haft meira en nóg að gera á undanförnum áratugum, prátt fyrir að tannheilsa hafi orðið sífellt betri. Hvernig má pað vera? Getur pað pýtt að eftirspurn eftir tannlækningum er nánast óendanleg og pví purfi stöðugt að mennta fleiri tannlækna og sérfræðinga til að mæta pessari eftirspurn?" Yfirvöld telja svo vera. Statistiske sentralbyrå (SSB) álýtur að með sömu fjölgun tannlækna og verið hefur á 20 árum verði til skortur á 1.550 tannlæknum í almennum praxís. Heilbrigðisráðuneytið er sömu skoðunar og pörf sé á fleiri en 300 nýjum sérfræðingum á næstu tíu árum eða 80\% miðað við núverandi stöðu. Jostein Grytten geldur hins vegar varhug við fjölgun tannlækna verði eins mikil og hið opinbera telur pörf á. pað gæti haftí för með sér skort á verkefnum, sérstaklega meðal ungra tannlækna (30).

Á áttunda áratugnum var meðferð eldri sjúklinga í Noregi með heilgómum algeng. Nú halda Normenn tönnum sínum lengur og sætta sig ekki við annað en að haldið sé í tennur ef gerlegt er og tapaðar tennur bættar með föstu tanngervi. Kaupmáttur sjúklinga jókst verulega, rauntekjur á mann næstum tvöfaldast frá 1970 til í dag. Noregur

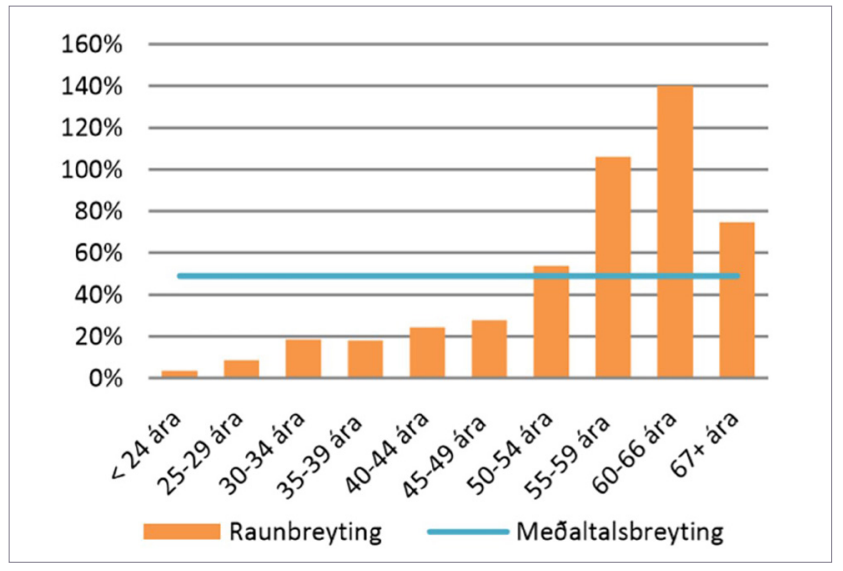

Mynd 7. Raunbreyting ráđstöfunartekna 2000-2015. Heimild: Landsbankinn, Hagfræðideild (28).

Figure 7. Change in disposable income between year 2000 - 2015 at fixed prices. Source: Landsbankinn, Economics (28).

breyttist frá frá pví að vera fátækt land í að verða ríkast OECD-landa(30). Telja verður að á Íslandi sé staðan svipuð og í Noregi nema hvað Íslendingar eru nokkrum árum á eftir hvað pátttöku hins opinbera í tannlæknakostnaði varðar. Ísland blandar sér í toppsæti OECD ríkja með Noregi (30).

Í Svíðpjóð var fjöldi íbúa á tannlækna 2017 svipaður og á Íslandi eða nálægt 1200. Nú er verulegur skortur á tannlæknum og tannfræðingum, en Svíar fækkuðu tannlæknnemum um $40 \%$ á níunda áratugnum, sem er að koma peim nú í koll eins og hjá Dönum. I 18 héruðum (landsting/regioner) af 20 er skortur og margar aðgerðarstofur standa auðar $(11,31)$. SCB, Statiska centralbyrån, spáir skorti á tannlæknum og tannfræðingum miðað við mannfjöldaspár, aldursamsetningu pjóðarinnar og peirra sem veita pjónustuna. Fram kemur í rannsókn SCB hjá rekstraraðilum að í $80 \%$ tilfella sé skortur á reyndum tannlæknum og 60\% telja skort á nýútskrifuðum tannlæknum (31). Sænska tannlæknablaðið birti röð greina í byrjun ársins sem fjölluðu um tannlæknaskortinn og hvernig ætti að bregðast við honum. Chaim Zlotnik, nýr formaður sænska tannlæknafélagsins, vill ekki gera eins mikið úr skortinum, segir hann fyrst og fremst utan borga og bæja og segir fjölda íbúa á tannlækni svipaðan og í öðrum Evrópulöndum (11).

Athyglisvert er að Norðmenn með um 1100 íbúa á tannlækni, Svía með um 1200 á tannlækni og Dani með rúmlega 1000 íbúa á tannlækni, pjóðir sem nota mikið aðstoðarfólk, tannfræðinga og tanntækna, búa nú pegar við og sjá fram á umtalsverðan skort á starfsliði við tannlækningar á komandi árum. 


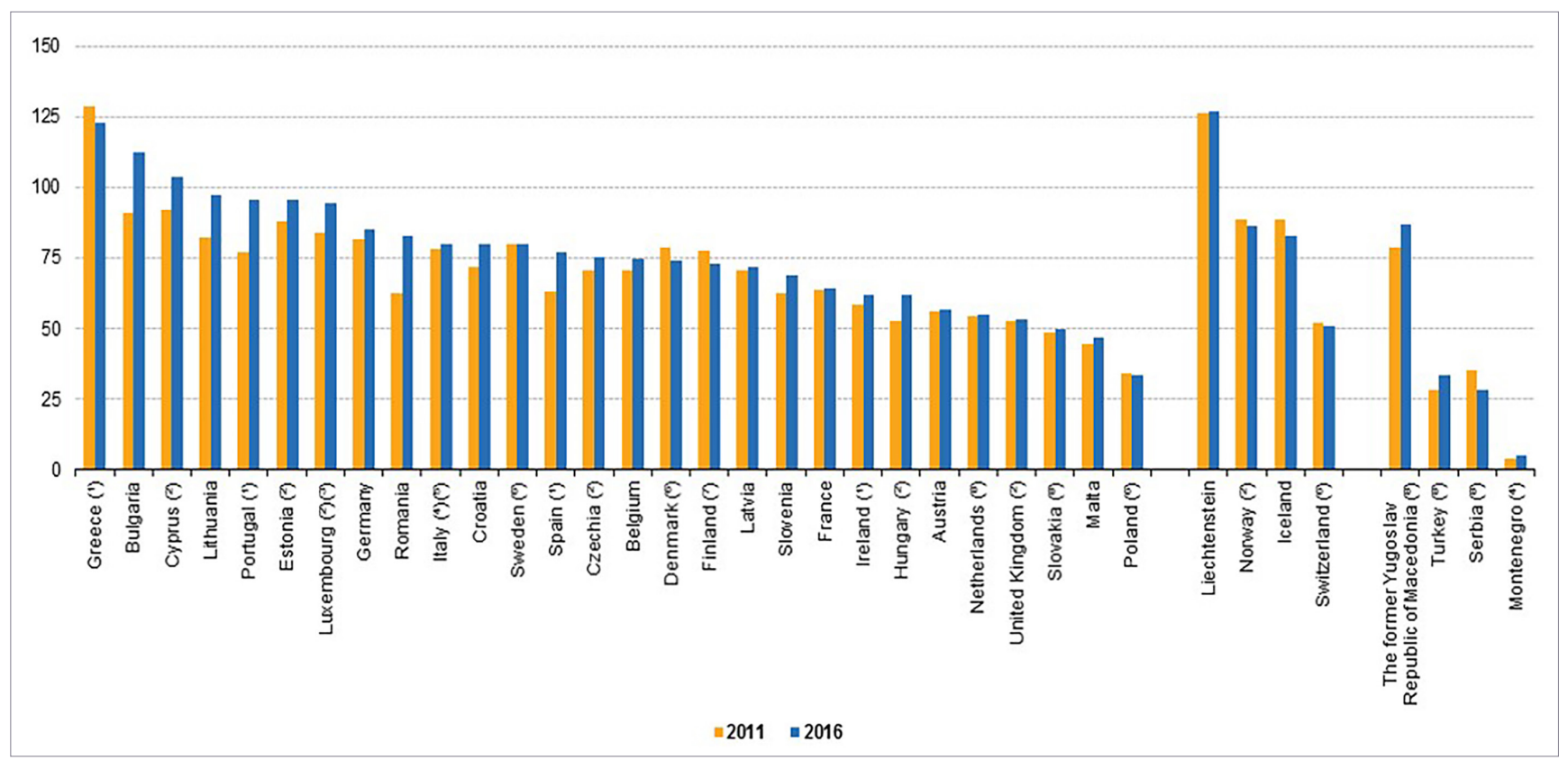

Mynd 8. Fjöldi starfandi tannlækna 2011 og 2016 á hverja 100.000 ibúa i Evrópu. Heimild: Eurostat (32).

Figure 8 . Number of practising dentists 2011 and 2016 per 100.000 inhabitants. Source: Eurostat (32).

Á Mynd 8 eru upplýsingar frá Eurostat um fjölda starfandi tannlækna á 100.000 íbúa í Evrópu, annars vegar 2011 og 2016 (32). Sjá má sjá að fjöldinn hér er nánast sá sami og í Noregi, aðeins færri í Svípjóð, Danmörku og Finnlandi. Athygli vekur hversu hátt hlutfall tannlækna er í Grikklandi.

Konur voru helmingur starfandi tannlækna í Evrópu árið 2015 (32). Árið 2018 voru konur 42\% starfandi tannlækna á Íslandi (Mynd 2). Mikill meirihluti tannlæknanema hér á landi eru konur. Ekki er vitað um starfshlutfall sjálfstætt starfandi tannlækna á Íslandi.

Íslenskir tannlæknar eru ekki eins duglegir að deila verkefnum með tannfræðingum og tanntæknum og kollegar peirra annars staðar í Evrópu. Samkvæmt upplýsingum Félags tanntækna og aðstoðarfólks tannlækna (FTAT) í september 2018 voru 290 félagsmenn starfandi. Ekki er vitað um starfshlutfall. Að jafnaði er einn aðstoðarmaður á hvern tannlækni, en séu hlutastörfin áætluð í heilsdagsstörf næst varla pað hlutfall. í Noregi og á Íslandi er að meðaltali einn aðstoðarmaður á hvern tannlækni. Í Danmörku eru peir 1.7, í Finnlandi 1.6 og í Svípjóð 2.2 aðstoðarmenn á hvern tannlækni. Annars staðar í Evrópu er hlutfallið mjög breytilegt. Meirihluti grískra og franskra tannlækna kjósa að vinna án klínikaðstoðar. Í pýskalandi eru 2.2 aðstoðarmenn á hvern tannlækni og 1.6 í Bretlandi (17). Tannfræðingar eru hlutfallslega færri á Íslandi en annars staðar á Norðurlöndum. Í Svípjóð voru peir 3749 árið 2015, tveir tannlæknar á hvern tannfræðing. Sama hlutfall er í Danmörku. Í Finnlandi eru prír tannlæknar fyrir hvern tannfræðing og í Noregi fjórir (31).

\section{Ályktun}

Með svipuðum fjölda tannlækna frá Tannlæknadeild Háskóla Íslands og i l ljósi verulegrar aukningar á pátttöku hins opinbera i tannlækningakostnaði aldraðra og öryrkja frá 1. september 2018 og nánast fríum tannlækningakostnaði barna sem tók að fullu gildi 1. janúar 2018, munu verkefni íslenskra tannlækna fara vaxandi. Fleiri íbúar verða á hvern tannlækni hér á landi en í Danmörku, Noregi og Svípjóð. Tannlækningar eldri borgara er og verður verkefni sem takast verður á við. Tannvernd tenntra, lasburða aldraðra einstalinga inni á vistheimilum verður krefjandi og tímafrekt viðfangsefni. Telja verður að atvinnuhorfur tannlækna séu pví góðar. Nýjar rannsóknir á tannheilsu pjóđarinnar skortir til opinberar stefnumótunar í tannheilbrigðismálum pjóðarinnar.

\section{Heimildir}

1. Háskóli Íslands, stjórnsýsluúttekt. Ríkisendurskoðun, 2005: 26-28.

2. LíN, upplýsingar fengnar 4. október 2018.

3. Eurostat. Fertility statistics. Eurostat online puplication. 2019.

4. Hagstofa Íslands. Frjósemi aldrei verið minni. Talnaefni. 2019.

5. Hagstofa İslands. Félagsleg velferð innflytjenda á Íslandi. Félagsvísar: Sérhefti um innflytjendur - Hagtíðindi. 2019.

6. Hagstofa Íslands. Innflytjendum heldur áfram að fjölga. Talnaefni. 2018.

7. Ferðamálastofa. 2,3 milljónir erlendra farpega 2018. 2019.

8. World Health Organization. Oral health. World Health Report 2018, sótt 21 júlí 2019.

9. Guð̋laugsson JÓ, Guðmundsdóttir H, Jónsson. SH. Samband menntunar og munnheilsu. Rannsóknir í Félagsvísindum Félagsvísindastofnun Háskóla 2009:363 - 75. 
10. Singh A, Peres MA, Watt RG. The Relationship between Income and Oral Health: A Critical Review. J. Dent. Res. 2019;98(8):853-60.

11. Sievers J. Brist eller balans? Många perspektiv på tandläkarbristen. Tandläkartidningen. 2019(4):9-10.

12. Thoroddsen B, Richter S, Eliasson ST. Fjöldi tannlækna á Íslandi - spá um fjölda tannlækna fram til 2030. Number of dentists in Iceland - estimated number of dentists to the year 2030. Icelandic Dent J. 2008;26:33-8.

13 Hagstofa Íslands. Landsmönnum fjölgaði um 1.730 á fyrsta fjórðungi ársins. Talnaefni. 2019.

14. Hagstofa İslands. Landsmönnum fjölgar um 3\%. Talnaefni. 2018.

15. Hagstofa Íslands. Íbúar landsins 436 púsund árið 2067. Hagtiððindi. 2018.

16. Burlund A. Hver 8. tandlæge er over pensionalderen. Tandlægebladet DTF. 2019;5:426-7.

17. Kravitz A, Bullock A, Cowpe J, Barnes E. EU Manual of Dental Practice 2015. The Council of European Dentists. 2015(5.1):55.

18. Sigbjörnsdóttir HB, Jón Óskar Guðlaugsson JÓ, Jónsson SH. Heilsa og líðan Íslendinga 2017. Framkvæmdarskýrsla. Embætti landlæknis. 2018.

19. Eliasson S. Lækkun á tî̋ni tannátu í fullorð̋instönnum og unglingum á Íslandi. Tannlæknablaðið. 2002;20:19-24.

20. Embætti landlæknis. MUNNÍS 2007. Landsrannsókn á munnheilsu barna og unglinga. Kynning á fyrstu niðurstöđum Munnís-rannsóknarinnar. Embætti landlæknis. 2007.

21. Axelsson G, Helgadottir S. Edentulousness in Iceland in 1990. A national questionnaire survey. Acta odontologica Scandinavica. 1995;53(5):279-82.

22. Axelsson G, Helgadóttir S, Sigurgeirsdóttir E. Heilbrigððisáætlun til ársins 2010. Tannlæknablaðið. 2003;21(1):24-5.
23. Axelsson G, S. H. Breytingar á tannheilsu Íslendinga 1985-2000. Annar áfangi: Tannheilsa Íslendinga áriơ 1990. Tannlækningastofnun, Háskólaútgáfan. 1993.

24. Axelsson G, Sigurgeirsdóttir $E$, Helgadottir S. Breytingar á tannheilsu Íslendinga 1985-2000. Fjórði áfangi: Tannheilsa Íslendinga árið 2000. Tannlækningastofnun, Háskólaútgáfan. 2004.

25. Axelsson G, pórsson $\mathrm{H}$, Sæmundsson SR. Breytingar á tannheilsu Î́lendinga 1985-2000. Priðji áfangi: Tannheilsa Íslendinga árið 1995. Tannlækningastofnun, Háskólaútgáfan. 1999.

26. landlæknis E. Fleiri halda eigin tönnum lengur. Talnabrunnur, Fréttabréf landlæknis um heilbrigðisupplýsingar. 2018;12(7).

27. Guðjónsson KS. Hálaunalandið Ísland. Vísbending. 2018.

28. Hagfræð̈ideild Landsbankans. Raunbreyting ráđstöfunartekna 2000-2015. Hagsjá Heimilin. 2016.

29. Sundhedsstyrelsen. Tandplejeprognose 2018-2040. Udbuddet af personale i tandplejen. Statistikbankendk. 2019:9-54.

30. Dyvi EB. Fremtiden er usikker. Nor Tannlegeforen Tid. 2017;127:168-73.

31. Socialstyrelsen. Bedömning av tillgång och efterfrågan på personal $\mathrm{i}$ hälso- och sjukvård och tandvård Nationella planeringsstödet 2018. Socialstyrelsen. 2018;2(13):1-97.

32. Eurostat. Practising dentists, 2011 and 2016 (per 100000 inhabitants). Eurostat, statistics explaned online. 2018.

English Summary

\section{Number of dentists in Iceland \\ - estimated number of dentists to the year 2040}

BÖRKUR THORODDSEN, DMD.

SVEND RICHTER, DDS, DMD MSC, ASSOCIATE PROFESSOR EM., UNIV. OF ICELAND, FACULTY OF ODONTOLOGY

SIGFÚS PÓR ELÍASSON, MSC, PROFESSOR EM., UNIV. OF ICELAND, FACULTY OF ODONTOLOGY, SCIENTIST, NIOM, OSLO, NORWAY ICELANDIC DENTAL JOURNAL 2019; 37: 16-26

doi: 10.33112/tann.37.1.2

April 1. 2019 there were 358.780 inhabitants and 284 dentists in Iceland or 1.263 inhabitants per dentist, but 1.103 if only Icelandic citizens are counted. Recent population projection from Statistics Iceland indicates that the population of Iceland will significantly increase in the coming years. Number of elderly people will increase proportionally more than young people because of increased longevity and decreasing birth rate. If all dentists would retire at 67 years of age, there would be in this year 1416 inhabitants per dentist, but 1237 if recent immigrants are excluded. If 8 dentists graduate yearly from the Univ. of Iceland and one from abroad, it can be estimated, using the same assuptions and if mid projections of Statistics Iceland prove true, there will be 1.356 inhabitants per dentist in 2030, and almost unchanged ratio in 2040. If only inhabitants with citizenship are counted, the ratio would be 1.185 in the year 2030 and almost same in 2040. If all dentists would retire at 70, corresponding numbers in the year 2030 would be 1.295 for all inhabitants and 1.100 if only citizens are counted. It is, therefore, supposed that the professional outlook for dentists inceland is good and sufficient number of dentists will be available in the next decades. It is also assumed that dental service for dentate senior citizens, especially feeble and sick in homes for old people, will be a demanding and time-consuming task in the future. Epidemiological research on dental health is urgently needed in Iceland to be able to shape a strategy and dental health policy for the future.

Keywords: Dental Demographics, Dental Workforce, Iceland Correspondence: Börkur Thoroddsen, e-mail: bthor@xnet.is 